\title{
PENYELESAIAN SENGKETA KETERBUKAAN INFORMASI PUBLIK MELALUI AJUDIKASI DALAM UNDANG-UNDANG NOMOR 14 TAHUN 2008 TENTANG KETERBUKAAN INFORMASI PUBLIK
}

\author{
ARIF WIDI FATONI, S.H. \\ Magister Hukum Universitas Semarang
}

\begin{abstract}
ABSTRAK
Perkembangan teknologi Informasi yang sangat cepat berdampak pada tuntutan pelayanan informasi publik yang lebih optimal. Sehingga lembaga publik juga dituntut untuk melaksanakan ketentuan sesuai yang di amahkan undang-undang keterbukaan informasi publik. Dalam pelayanan publik sangat dibutuhkan tanggapan atau pelayanan yang cepat sehingga dalam pelayanan tidak menimbulkan adanya sengketa keterbukaan informasi publik yang diajukan oleh pemohon informasi ke Komisi Informasi Publik. Karena adanya pengajuan sengketa tentu saja Komisi Informasi Publik akan menyelesaikan melalui ajudikasi. Untuk itu standar operasional proedur dalam permintaan informasi pada lembaga publik atau penyedia informasi harus dilaksanakan dengan baik.

Perumusan masalahnya adalah cara penyelesaikan sengketa serta mengetahui kendala dan solusi penyelesaian sengketa keterbukaan informasi publik melalui ajudikasi sesuai dengan Undang-Undang Nomor 14 Tahun 2008 Tentang Keterbukaan Informasi Publik.

Pendekatan Penelitian adalah yuridis normatif, dalam mengadakan pendekatan serta prinsip-prinsip dan peraturan-peraturan yang masih berlaku untuk meninjau, melihat serta menanalisa permasalahan yang menjadi objek penelitian, serta dalam pendekatan juga melihat kenyataan yang ada dalam prakteknya.

Berdasarkan hasil penelitian dapat disimpulkan bahwa : 1) Dalam penyelesaian sengketa melalui ajudikasi dilakukan oleh tiga orang komisioner dalam sidang terbuka dan keputusannya disampaikan kepada para pihak yang bersengketa, 2) Kendala dalam penyelesaian sengketa informasi melalui ajudikasi adalah diperlukan waktu yang lama dalam menghadirkan pemohon dan termohon sehingga solusinya adalah komisi informasi diberi wewenang dalam eksekusi agar prosesnya lebih efektif.
\end{abstract}

Kata kunci : Sengketa, Keterbukaan Informasi Publik, Ajudikasi 


\title{
DISPUTE SETTLEMENT OF PUBLIC INFORMATION DISCLOSURE THROUGH ADJUDICATION IN LAW NUMBER 14 OF 2008 CONCERNING PUBLIC INFORMATION DISCLOSURE
}

\author{
ARIF WIDI FATONI, S.H. \\ Magister of Law Universitas Semarang
}

\begin{abstract}
ABSTRACT

The rapid development of information technology has an impact on the demands of more optimal public information services. So that public institutions are also required to implement the provisions according to the public information disclosure law. In public service, a response or service is urgently needed so that the service does not cause a dispute over public information disclosure submitted by the information applicant to the Public Information Commission. Because of the dispute submission, of course, the Public Information Commission will complete it through adjudication. For this reason, the standard operating procedures in requesting information from public institutions or information providers must be carried out properly.

The formulation of the problem is the method of resolving disputes as well as knowing the obstacles and solutions to dispute resolution of public information disclosure through adjudication in accordance with Law Number 14 of 2008 concerning Public Information Openness.

Research approach is normative juridical, in making approaches and principles and regulations that are still valid to review, see and analyze problems that are the object of research, and in the approach also see the reality that exists in practice.

Based on the results of the study, it can be concluded that: 1) In dispute resolution through adjudication carried out by three commissioners in an open session and their decisions submitted to the disputing parties, 2) Constraints in resolving information disputes through adjudication are required a long time in presenting applicants and defendants so the solution is that the information commission is authorized to execute so that the process is more effective.
\end{abstract}

Keywords: Disputes, Public Information Openness, Adjudication 


\section{LATAR BELAKANG}

Informasi

merupakan

kebutuhan mendasar bagi setiap

orang untuk mengembangkan kepribadian di lingkungan

soasialnya sehingga hak untuk memperoleh informasi merupakan hak asasi manusia yang wajib untuk dilindungi oleh Pemerintah. Sesuai yang di amanahkan Undang-Undang Dasar 1945 pasal 28F yang berbunyi setiap orang berhak untuk berkomunikasi dan memperoleh informasi untuk mengembangkan pribadi dan lingkungan sosilanya, serta berhak untuk mencari, memperoleh, memiliki, menyimpan, mengolah dan menyampaikan informasi dengan menggunakan segala jenis saluran yang tersedia.

Dalam doktrin welfare state atau negara kesejahteraan bahwa tugas pemerintah bukan lagi sebagai penjaga malam dan tidak boleh pasif tetapi harus berperan aktif dalam kegiatan masyarakat sehingga kesejahteraan bagi semua rakyatnya tetap terjamin, dengan demikian pemerintah harus memberi perlindungan bagi warga negara bukan hanya dibidang politik, tetapi juga dalam bidang sosial ekonomi, sehingga kesewenang-wenangan dari golongan tertentu harus dicegah oleh pemerintah, oleh sebab itu tugas pemerintah diperluas dengan maksud untuk menjamin kepentingan umum sehingga lapangan tugasnya mencakup berbagai aspek kehidupan masyarakat. $^{1}$

Proses semangat reformasi yang terjadi di Indonesia melahirkan perubahan paradigma dalam perubahan politik dan ketatanegaraan di Indonesia yaitu dari sistem otoritarian kedalam sistem demokratis, ${ }^{2}$ sehingga terjadi perkembangan dan pola pikir yang menyeluruh. Konsepsi Trias Politica saat ini dirasa sudah tidak relevan lagi dalam pelaksanaan demokrasi, karena mengingat tidak mungkin lagi mempertahankan ketiga organisasi tersebut hanya berurusan secara eksekutif dengan salah satu dari ketiga fungsi dari

${ }^{1}$ SF. Marbun dan Muh Mahfud MD, PokokPokok Hukum Administrasi Negara, Liberty, Yogyakarta : 1987, hlm. 45.

Emilda Firdaus, Badan Permusyawaratan Desa Dalam Tiga Pemerintahan Di Indonesia, Jurnal IImu Hukum Fakultas Hukum Riau Vol 1, No 02, Pekanbaru : 2011, hlm. 3. 
kekuasaan tersebut. Sehingga kenyataan dewasa ini menunjukkan hubungan antar cabang kekuasaan itu tidak mungkin tidak saling bersentuhan, dan bahkan ketiganya bersifat sederajat dan saling mengendalikan satu sama lain sesuai dengan prinsip check and balances. $^{3}$

Manusia dan hukum yang berkeadilan, serta tata pemerintahan yang baik atau good governances, pemerintahan yang bersih atau clean goverments dan bertanggung jawab (baik dalam skala nasional maupun global) terhadap struktur ketatanegaraan yang diharuskan memperhatikan konsep-konsep atau ide-ide mengenai hak asasi manusia dan demokrasi. ${ }^{4}$

Dengan demikian pengelolaan Pemerintahan yang baik, mensyaratkan bahwa Pemerintah harus terbuka serta

\footnotetext{
Asshiddiqie, Jimly. 2006. Perkembangan dan Konsolidasi Lembaga Negara Pasca Reformasi. Jakarta. Sekretariat Jendral dan Kepaniteraan Mahkamah Konstitusi RI, hIm. Vii.

${ }^{4}$ Firmansyah Arifin et al, Lembaga Negara dan sengketa kewenangan antar Lembaga Negara, Konsorsium reformasi hukum Nasional bekerja sama dengan Makhkamah Konstitusi Republik Indonesia, Konsorsium Reformasi Hukum Nasional $(K R H N)$, Jakarta : 2005, hlm.1.
}

kebebasan memperoleh informasi untuk menjadi salah satu pokoknya. Pemerintahan yang terbuka mensyaratkan adanya lima jaminan; pertama, hak untuk memantau segala perilaku pejabat publik dalam menjalankan perannya; kedua, hak untuk memperoleh informasi; ketiga, hak untuk terlibat dan berpartisipasi dalam proses pembentukan kebijakan publik; keempat, kebebasan berekspresi; kelima, hak untuk mengajukan keberatan terhadap penolakan atas keempat tersebut diatas.

$$
\text { Walaupun sudah ada }
$$

paradigma

perubahan penyelenggaraan pemerintahan melalui tata kelola keterbukaan informasi publik, namun dalam tataran empiris pelayanan publik juga masih mengalami hal yang mendasar yaitu masih adanya ketertutupan dan bahkan informasi tata kelola keterbukaan juga masih sedikit memberikan informasi yang berkaitan dengan kebijakankebijakan publik. Yang menjadi permasalahan adalah informasi tidak disampaikan secara jelas 
sehingga objek informasi tersebut menjadi sengketa informasi.

Sengketa informasi muncul ketika badan publik dan pengguna informasi berkaitan dengan hak-hak memperoleh informasi dan menggunakan informasi berdasarkan perundang-undangan yang berkaitan dengan keterbukaan informasi publik. Komisi Informasi yang merupakan Lembaga Independen yang bertugas menjalankan UndangUndang Keterbukaan Informasi Publik, menetapkan petunjuk teknis standar layanan informasi publik dan peraturan pelaksanaanya serta menyelesaikan sengketa informasi publik melalui mediasi atau ajudikasi non litigasi.

Namun ajudikasi masih menyimpan permasalahan karena apabila dalam tenggang waktu 14 hari kerja sejak salinan putusan Komisi Informasi diterima oleh para pihak berdasarkan tanda bukti penerimaan, dalam hal salah satu atau para pihak tidak mengajukan keberatan, maka putusan Komisi Informasi berkekuatan hukum tetap. Dan putusan ajudikasi Komisi Informasi merupakan objek Tata
Usaha Negara sesuai pasal 47 Undang-undang Nomor 14 Tahun 2008.

Maka putusan komisi informasi itu bisa dibanding dan digugat oleh para pinak dan eksekusinya tetap berada di pihak peradilan umum dalam hal ini ketua pengadilan sementara untuk delik aduan pidana pada pihak kepolisian, dengan mekanisme seperti itu tidak menggambarkan bahwa putusan komisi informasi itu lemah dan rawan di intervensi. Sehingga putusan Komisi Informasi bisa dibatalkan apabila Majelis Komisioner tidak cermat.

Untuk itu penulis sangat tertarik untuk menyusun penelitian dengan judul "PENYELESAIAN SENGKETA KETERBUKAAN INFORMASI PUBLIK MELALUI AJUDIKASI DALAM UNDANG UNDANG NOMOR 14 TAHUN 2008 TENTANG KETERBUKAAN INFORMASI PUBLIK".

\section{RUMUSAN PENELITIAN}

Berdasarkan uraian dalam latar belakang, maka dapat dirumuskan permasalahan dalam penelitian ini sebagai berikut: 
1. Bagaimana Penyelesaian

Sengketa Keterbukaan Informasi

Publik Melalui Ajudikasi Sesuai

Dengan Undang-Undang Nomor

14 Tahun 2008 Tentang

Keterbukaan Informasi Publik?

2. Bagaimana Kendala Dan Solusi

Atas Penyelesaian Sengketa

Keterbukaan Informasi Publik

Melalui Ajudikasi Dalam Kajian

Undang-Undang Nomor 14

Tahun 2008 Tentang

Keterbukaan Informasi Publik?

\section{METODE PENELITIAN}

Metode yang digunakan dalam penelitian ini adalah yuridis normatif, yaitu dititik beratkan pada penggunaan data kepustakaan atau data sekunder yang berupa bahan hukum primer, sekunder dan tersier. Metode pendekatan yang digunakan dengan mengingat bahwa permasalahan yang diteliti berkisar pada peraturan perundang-undangan yaitu hubungan peraturan yang satu dengan yang lainya serta kaitannya dengan penerapannya dalam praktek. Selanjutnya penelitian yang dilakukan oleh penulis dalam penelitian ini lebih ditujukan kepada pendekatan undang-undang (statute approach) dan pendekatan kasus (case approach). Pendekatan undang-undang dilakukan dengan menelaah semua undang-undang dan regulasi terkait isu hukum yang dibahas dalam penelitian ini. Pendekatan kasus dilakukan dengan cara melakukan telaah terhadap kasus-kasus yang berkaitan dengan isu yang dibahas dalam penelitian ini. ${ }^{5}$

PEMBAHASAN

A. Penyelesaian Sengketa Keterbukaan Informasi Publik Melalui Ajudikasi Sesuai Dengan Undang-Undang Nomor 14 Tahun 2008 Tentang Keterbukaan Informasi Publik.

Setiap Badan Publik mempunyai kewajiban untuk membuka akses atas Informasi Publik yang berkaitan dengan Badan Publik tersebut untuk masyarakat luas pada umumnya. Lingkup Badan Publik dalam Undang-undang Nomor 14 Tahun 2008 Tentang Keterbukaan Informasi Publik meliputi lembaga

5 Riduan Syahrani, Rangkuman Intisari Ilmu Hukum, Penerbit Citra Aditya Bakti, Bandung, 1999, hlm.94. 
eksekutif, yudikatif, legislatif, serta penyelenggara negara lainnya yang mendapatkan dana dari Anggaran Pendapatan dan Belanja Negara (APBN)/Anggaran Pendapatan dan Belanja Daerah (APBD) dan mencakup pula organisasi non pemerintah, baik yang berbadan hukum maupun yang tidak berbadan hukum, seperti lembaga swadaya masyarakat, perkumpulan, serta organisasi lainnya yang mengelola atau menggunakan dana yang sebagian atau seluruhnya bersumber dari APBN/APBD, sumbangan masyarakat, dan/atau luar negeri.

Sesuai dengan yang diamanat pasal 13 UU No. 14 Tahun 2008 setiap Badan Publik menunjuk Pejabat Pengelola Informasi dan Dokumentasi (PPID) dan membuat dan mengembangkan sistem penyediaan layanan informasi secara cepat, mudah, dan wajar sesuai dengan petunjuk teknis standar layanan Informasi Publik yang berlaku secara nasional. ${ }^{6}$

${ }^{6}$ Dwight Waldo, 1984. Pengantar Studi Public Administration, Cetakan Keempat, Alih Bahasa Slamet W. Admosoedarmo, Aksara Baru, Jakarta, hal. 86
Hal ini merupakan langkah awal bekerjanya PPID sesuai dengan tugas dan tanggung jawabnya untuk mewujudkan pelayanan cepat, tepat, dan sederhana setiap Badan Publik. Peraturan Pemerintah No. 61 Tahun 2010 mengamanatkan PPID harus sudah ditunjuk paling lama 1 (satu) tahun terhitung sejak peraturan pemerintah diundangkan pada tanggal 23 Agustus 2010.

Keberadaan Undang-undang Nomor 14 Tahun 2008 tentang Keterbukaan Informasi Publik sangat penting sebagai landasan hukum yang berkaitan dengan :

1. hak setiap Orang untuk memperoleh Informasi;

2. kewajiban Badan Publik menyediakan dan melayani permintaan Informasi secara cepat, tepat waktu, biaya ringan/proporsional, dan cara sederhana;

3. pengecualian bersifat ketat dan terbatas;

4. kewajiban Badan Publik untuk membenahi sistem dokumentasi dan pelayanan Informasi.

Melalui mekanisme dan pelaksanaan prinsip keterbukaan, 
akan tercipta kepemerintahan yang baik dan peran serta masyarakat yang transparan dan akuntabilitas yang tinggi sebagai salah satu syarat untuk mewujudkan demokrasi yang hakiki. Dengan membuka akses publik terhadap Informasi yang diharapkan Badan Publik termotivasi untuk bertanggung jawab dan berorientasi pada pelayanan rakyat yang sebaik-baiknya. Dengan demikian, hal itu dapat mempercepat perwujudan pemerintahan yang terbuka yang merupakan upaya strategis mencegah praktik korupsi, kolusi, dan nepotisme (KKN), dan terciptanya kepemerintahan yang baik (good governance). ${ }^{7}$

Adapun upaya-upaya yang dapat dilakukan untuk menyelesaikan sengketa informasi publik adalah diawali dengan adanya upaya keberatan yang ditujukan kepada badan penyedia informasi, apabila tidak mendapatkan jawaban atau tanggapan yang memuaskan, maka dapat melakukan laporan atau

${ }^{7}$ Miftah Thoha, 2003. Birokrasi dan Politik di Indonesia, Cetakan Kedua, RajaGrafindo Persada, Jakarta. Hal 112. pengaduan melalui Komisi Informasi, Komisi informasi akan melakukan persidangan sesuai dengan standart yang berlaku, dan akan memanggil para pihak untuk dimintakan keterangan, setelah mendapatkan keterangan yang memadai, Komisi Informasi Publik akan memutuskan sengketa yang dimintakan oleh yang tidak puas dengan adanya informasi yang diberikan oleh instansi atas lembaga yang menjadi terlapor. ${ }^{8}$ Apabila para pihak masih belum puas, maka pemohon informasi dapat melakukan upaya keberatan melalui Pengadilan, sesuai dengan ketentuan yang berlaku.

B. Kendala Dan Solusi Atas Penyelesaian Sengketa Keterbukaan Informasi Publik Melalui Ajudikasi Dalam Kajian Undang-Undang Nomor 14 Tahun 2008 Tentang Keterbukaan Informasi Publik.

Salah satu kendala yang menyebabkan proses ajudikasi memakan waktu yang lama adalah

${ }^{8}$ Suwandi, Made.2009. Tanggapan Terhadap Makalah Tentang Pokok-Pokok Pikiran Penataan Organisasi Pemerintah Pusat, Pemerintah Daerah Propinsi dan Pemerintah Daerah Kabupaten/Kota, Jakarta. Hal. 81 
kehadiran pemohon dan termohon. Untuk mengumpulkan majelis komisioner yang telah ditunjuk untuk menangani proses ajudikasi cukup memakan waktu sebab para komisioner juga mempunyai pekerjaan lain diluar sebagai komisioner contohnya adalah advokat. Salah satu dari pihak termohon ataupun termohon juga kadang berhalangan hadir sehingga Komisi Informasi mesti membuat sidang ulang karena sidang tidak dapat dilanjutkan jikalau majelis cuma menerima informasi dari salah satu pihak saja yang bersengketa.

Makanya komisioner dalam majelis komisioner paling utama wajib hadir pada saat tahap pengambilan keputusan. Beliau juga menjelaskan pada tahap pengambilan keputusan ketika salah satu majelis komisioner berbeda pendapat dengan majelis lainnya maka ada solusi yang dinamakan decending opinion. Decending opinion adalah pernyataan dari salah satu pihak majelis yang tidak setuju dengan keputusan majelis komisioner lain untuk membuka informasi. Namun, jika kedua majelis komisioner yang lain setuju untuk membuka informasi maka keputusan final tetap mengikuti suara terbanyak dengan memberi catatan bahwa salah satu komisioner tidak menyetujuinya.

Kurangnya pemahaman akan Undang-Undang keterbukaan informasi pada instansi maupun masyarakat dan tidak terbukanya badan publik menjadi dua kendala yang menurut Bapak Slamet Hariyanto selaku komisioner seringkali menghambat proses ajudikasi sehingga mengakibatkan pihak termohon menolak hadir atau mengutus perwakilan untuk datang menghadiri sidang di Komisi Informasi Publik padahal pihak komisioner ingin berbicara secara langsung dengan pihak pengambil keputusan suatu badan publik tersebut.

Seharusnya Komisi Informasi sudah mempunyai wewenang eksekusi maka proses ajudikasi akan jauh lebih efektif, akan tetapi wewenang eksekusi masih berada di pengadilan sehingga bila menghadapi kasus seperti ini termohon menolak memberikan 
suatu informasi sekalipun sudah dikeluarkan surat keputusan, pemohon tinggal meregistrasi surat keputusan Komisi Informasi di pengadilan biar nanti pengadilan yang melaksanakan eksekusinya.

Budaya masyarakat yang belum terbuka sepenuhnya sehingga menjadi kendala belum efektifnya ajudikasi sementara Undang-Undang berasumsi bahwa budaya kita sudah sangat terbuka. Menurut saya bahwa proses ajudikasi ini baru akan efektif 5 tahun mendatang. Kasus suap juga kerap terjadi yang melibatkan kedua belah pihak yang bersengketa. Pelaku kasus seperti ini biasanya adalah LSM yang berusaha meraih keuntungan dari badan publik dengan berkedok meminta informasi ataupun yang lain. Ketika LSM mengajukan keinginannya semisal barang elektronik kepada badan publik maka saat keinginannya terpenuhi selesailah sudah masalah. Namun selaku komisioner menjadi kelemahan dari proses ajudikasi ini sehingga perlu diberlakukan aturan baru dalam Undang-Undang keterbukaan informasi semisal memasukkan ke penjara bagi oknum yang menjadikan kasus sengketa informasi lahan untuk mencari uang dan keluar masuk badan publik dengan tujuan mencari keuntungan.

Solusinya adalah komisioner dan staf harus banyak mengikuti berbagai macam pelatihan seputar mediasi dan ajudikasi di berbagai kota-kota besar yang masalahnya lebih beraneka ragam untuk menambah pengalaman. Masalah SDM bisa dicarikan alternatif dengan banyak berdiskusi dengan Komisi Informasi Pusat dalam beberapa kasus penyelesaian sengketa informasi. Berkat diskusi ini, para komisioner jadi lebih pandai dalam meyelesaikan kasus sengketa informasi dan mampu menghindari bias. Para komisioner dan staf di Komisi Informasi ini sangat qualified jadi apapun hambatannya komisioner dan staf pasti bisa menyelesaikan apapun kasus sengketa informasi yang masuk ke dalam Komisi Informasi Jawa Tengah.

Komisi Informasi harus bisa melayani masyarakat dengan lebih baik, sehingga dalam penyelesaian 
kasus sengketa informasi mampu memahami tentang pentingnya Undang-Undang keterbukaan informasi publik secara baik kepada badan publik maupun masyarakat luas. Ajudikasi adalah penyelesaian sengketa alternatif yang dilaksanakan oleh Komisi Informasi Publik akan tetapi masyarakat pada umumnya masih banyak yang belum mengetahui secara detail oleh sebab itu perlu adanya sosialisasi yang diadakan antara Pemerintah atau badan publik dengan Komisi Informasi Publik secara bersama-sama.

\section{PENUTUP}

\section{A. Kesimpulan}

1. Penyelesaian sengketa informasi publik melalui Komisi Informasi dilakukan karena adanya keberatan masyarakat terhadap Badan Publik yang tidak memberikan tanggapan atau jawaban yang memuaskan sehingga perselisihan antara kedua belah pihak tersebut diselesaikan di Komisi Informasi. Sesuai fungsi tugas dan wewenangnya maka Komisi Informasi memanggil para pihak yang bersengketa untuk diselesaikan secara mediasi. Proses mediasi dilakukan oleh mediator dan mediator pembantu yaitu dengan menelusuri dan menggali kepentingan mereka untuk mencapai kesepakatan, dan mediator mengusulkan agar kesepakatan para pihak memuat sanksi yang para pihak yang dikemudian hari tidak melaksanakan kesepakatan dan keputusan yang telah diambil. Namun apabila mediasi gagal atau tidak berhasil maka Komisi Informasi menggelar sidang ajudikasi yang mana untuk memutus perkara yang gagal seperti tersebut diatas. Putusan Komisi Informasi atas penyelesaian sengketa dengan ajudikasi berupa :

a. pemberian atau penolakan akses terhadap seluruh atau sebagian informasi yang diminta berisikan salah satu perintah.

b. Membatalkan putusan atasan badan publik dan memutuskan untuk memberikan sebagian atau seluruhnya informasi yang 
diminta oleh pemohon

informasi publik sesuai dengan keputusan Komisi Informasi.

c. mengukuhkan putusan atasan pejabat pengelola informasi dan dokumentasi untuk tidak memberikan informasi yang diminta baik sebagian atau seluruhnya.

d. putusan Komisi Informasi tentang pokok keberatan tidak disediakan informasi secara berkala yang meliputi; informasi tentang badan publik tersebut, kegiatan dan kinerjanya, laporan keuangannya dan/atau yang diatur oleh undang-undang, tidak ditanggapinya permintaan informasi; atau ditanggapi tidak sepenuhnya tidak dipenuhinya permintaan informasi, atau pengenaan biaya yang tidak wajar serta penyampaian informasi yang tidak tepat waktu.

e. memerintahkan pejabat pengelola informasi dan dokumentasi untuk menjalankan kewjibannya sebagaimana ditentukan oleh Undang-Undang.

f. memerintahkan Badan Publik untuk memenuhi kewajibannya dalam jangka waktu pemberian informasi sebagaimana diatur dalam UUKIP.

g. Mengukuhkan pertimbangan atasan Badan Publik atau memutuskan mengenai biaya penelusuran dan / atau penggandaan informasi.

2. Kendala yang menyebabkan

proses ajudikasi memakan waktu yang lama yaitu kehadiran pemohon dan termohon. Untuk mengumpulkan majelis komisioner yang telah ditunjuk untuk menangani proses ajudikasi cukup memakan waktu sebab para komisioner juga mempunyai pekerjaan lain diluar sebagai contohnya adalah advokat. Salah satu dari pihak termohon ataupun termohon juga kadang berhalangan hadir sehingga Komisi Informasi mesti membuat sidang ulang karena sidang tidak dapat dilanjutkan jikalau majelis cuma menerima informasi dari salah satu pihak 
saja yang bersengketa. Kurangnya pemahaman akan Undang-Undang keterbukaan informasi pada instansi maupun masyarakat dan tidak terbukanya badan publik menjadi dua kendala yang seringkali menghambat proses ajudikasi sehingga mengakibatkan pihak termohon menolak hadir atau mengutus perwakilan untuk datang menghadiri sidang di Komisi Informasi Publik padahal pihak komisioner ingin berbicara secara langsung dengan pihak pengambil keputusan suatu badan publik tersebut. Sehingga solusinya adalah banyak mengikuti pendidikan dan pelatihan agar menambah pengalaman yang lebih luas dalam menangani permasalahan.

Banyak melakukan diskusi agar para komisioner lebih pandai dalam menyelesaiakan sengketa informasi dan mampu menghindari hal-hal yang tidak diinginkan. Memahami UndangUndang Keterbukaan informasi publik serta mensosialisasikan dengan masyarakat luas maupun Badan Publik, karena dengan era globalisasi sekarang ini semua tekologi informasi berkembang dengan sangat cepat dan apabila kita tidak mengikuti akan ketinggalan.

\section{B. SARAN}

1. Bagi Pemerintah ajudikasi memakan waktu yang lama yaitu kehadiran pemohon dan termohon untuk mengumpulkan majelis komisioner yang telah ditunjuk untuk menangani proses ajudikasi sehingga cukup memakan waktu maka para komisioner yang mempunyai pekerjaan lain diluar sebagai komisioner contohnya adalah pengacara, maka sebaiknya lebih fokus akan pekerjaan sebagai komisioner karena komisioner adalah pekerjan pokok.

2. Bagi Komisi Informasi karena satu dari pihak termohon ataupun termohon juga kadang berhalangan hadir sehingga membuat sidang ulang karena sidang tidak dapat dilanjutkan jikalau majelis cuma menerima informasi dari salah satu pihak saja yang bersengketa 
sebaiknya Komisi Informasi memberi peringatan lebih tegas dan di beri sanksi. Karena era saat ini serba digital maka setiap komisioner ataupun asistennya harus di diklat supaya lebih bertambah wawasannya serta kompetensinya lebih baik dibandingkan dengan masyarakat umum. Komisi Informasi harus memberikan pemahaman dan wawasan yang luas akan pentingnya keterbukaan informasi publik dan tidak hanya men justice bahwa jika tidak melakukan uji konsekuensi akan di selesaikan dalam sidang di KIP sehingga menyebabkan kekhawatiran pada lembaga publik atau masyarakat.

3. Bagi masyarakat karena kurangnya pemahaman akan UU keterbukaan informasi pada instansi maupun masyarakat dan tidak terbukanya badan publik maka sebaiknya Komisi Informasi memberi sosialisasi kepada semua lembaga secara intensif tanpa menunggu undangan dari badan publik atau masyarakat.

\section{DAFTAR PUSTAKA} BUKU-BUKU

Ali Budiarto, 2005 Kompilasi Kaidah Hukum Putusan mahkamah Agung Hukum Acara perdata Masa Setengan Abad. Swara Justitia. Jakarta.

A Herbert Simon, 2004. Administrative

Behavior, Perilaku Administrasi : Suatu Studi tentang Proses Pengambilan Keputusan dalam Organisasi Administrasi, Edisi Ketiga, Cetakan Keempat, Alih Bahasa ST. Dianjung, Bumi Aksara, Jakarta.

Antar Lembaga Negara, 2005. Konsursium Reformasi Hukum Nasional, Jakarta.

Anshorie Sabuan, 1990. Hukum Acara Pidana,Penerbit Angkasa,Bandung.

Arifin Firmansyah DKK, 2008. Lembaga Negara dan Sengketa Kewenangan lembaga negara, Liberty, Yogyakarta.

Arifin, Firmansyah, et al. 2005. Lembaga Negara dan sengketa kewenangan antar Lembaga Negara, Konsorsium reformasi hukum Nasional. Bekerja sama dengan Makhkamah Konstitusi Republik Indonesia. Jakarta. Konsorsium Reformasi Hukum Nasional (KRHN).

Ashin Tohari, 2006. Kedudukan Komisi Negara dalam Struktur Ketatanegaraan, Rineka Cipta, Jakarta.

Asshiddiqie, Jimly. 2006. Perkembangan dan Konsolidasi Lembaga Negara Pasca Reformasi. 
Jakarta. Sekretariat Jendral dan Kepaniteraan Mahkamah Konstitusi RI.

Bintan R Saragih, 2004. KomisiKomisi Negara Dalam Sistem Pemerintahan Yang Berubah, Jakarta.

Bambang Sugeng dan Sujayadi. 2011. Hukum Acara Perdata Dan Dokumen Litigasi Perkara Perdata. Jakarta: Kencana.

Cst Kansil, 2002. Pengantar ilmu hukum dan tata hukum Indonesia, Balai Pustaka, Jakarta.

Darwin Rins, 1989. Hukum Acara Pidana: Suatu Pengantar. Jakarta: Djambatan.

Denny Indrayana, 2007. Amandemen UUD 1945, Penerbit Mizan, Bandung.

Dhoho A. Sastro et al. 2010. Mengenal Undang-Undang Keterbukaan Informasi Publik. Jakarta:Lembaga Bantuan Hukum Masyarakat.

Dwight Waldo, 1984. Pengantar Studi Public Administration, Cetakan Keempat, Alih Bahasa Slamet W. Admosoedarmo, Aksara Baru, Jakarta.

DY.Wiyanto, 2011. Hukum Acara Mediasi. Bandung: Alfabeta.

Elly Dar Chaidir, 2007. Negara Hukum Demokrasi dan Konstalansi Ketatanegaraan Indonesia, Kreasi Total Media, Yogyakarta.

Gunawan Abdullah Tauda, 2012. Kedudukan Komisi Negara Independen, Genta Press, Yogyyakarta.

Hans Kelsen, 2009. Teori Umum Tentang Hukum dan Negara, Nusa Media, Bandung.
Hari Sasangka, 2003. Hukum Pembuktian Dalam Perkara Perdata Untuk Mahasiswa Dan Praktisi. Mandar Maju.Bandung.

Hari Sasangka dan Lily Rosita, $2003 . \quad$ Hukum Pembuktian dalam Perkara Pidana, Mandar Maju, Bandung.

I Ketut Artadi, 2008. Kumpulan Peraturan Perundang Undangan Hukum Acara Perdata,( Diktat ) Fakultas Hukum, Universitas Udayana, Denpasar.

Irfan Islamy, 1994. Prinsip-prinsip Perumusan Kebijaksanaan Negara, Bumi Aksara Jakarta.

Jimlly Ashidiqie, 2006. Perkembangan dan Konsolidasi Lembaga Negara Pasca Reformasi, Sekertariat Jendral Kepaniteraan Mahkamah Konstitusi, Jakarta.

Jimly Ashidiqie , 2011. Beberapa Catatan Tentang LembagaLembaga Khusus dalam Penyelenggaraan

Pemerintahan Negara, Seminar Nasional LembagaLembaga Non Struktural, Kementerian Pertahanan, Maret

Kattopo, Dari Meja Tanri Abeng (2000). Managing atau Chaos, Jakarta: Institut Pembelajaran Manajemen Paramadina.

Luhut M.P.Pangaribuan, 2005. Hukum Acara Pidana,Suratsurat Resmi di Pengadilan oleh Advokat,Djambatan. 
Lukman Hakim, 2010. Kedudukan Hukum Komisi-Komisi Negara Di Indonesia, Setara Press, Group In Trans, Malang.

Martiman Prodjohamidjojo, 2001. Membuat Surat Dakwaan, Ghalia Indonesia, Jakarta.

Miftah Thoha, 2003. Birokrasi dan Politik di Indonesia, Cetakan Kedua, Persada, Jakarta.

Miriam Budiarjo, 1978. Dasar-Dasar IImu Politik, Gramedia, Jakarta.

Moh. Mahfud M.D, 1999. Hukum dan Pilar-Pilar Demokrasi, Gama Media, Yogyakarta.

Moh. Mahfud M.D, 2006. Politik Hukum, Gama Media, Yogyakarta.

Nurnaningsih Amriani, 2011. Mediasi Alternatif Penyelesaian Sengketa Perdata Di Pengadilan. Jakarta: PT. RajaGrafindo Persada.

Rachmadi Usman, 2012. Mediasi Di Pengadilan Dalam Teori Dan Praktik. Jakarta: Sinar Grafika.

Rozali Abdullah, 1994. Hukum Acara Peradilan Tata Usaha Negara, cet, ketiga, PT Raja Grafindo Persada, Jakarta.

SF. Marbun dan Muh Mahfud MD, 1987. Pokok-Pokok Hukum Administrasi Negara. Yogyakarta. Liberty.

Siti Soetami, 2005. Hukum Acara Peradilan Tata Usaha Negara, Aditama, Bandung. Soebekti, 2007. Hukum

Pembuktian. Pradnya

Paramita. Jakarta.

Soesilo Yuwono, 1982.

Penyelesaian

Perkara

Pidana
KUHAP: sistem dan Prosedur, Alumni, Bandung.

Stephen P Robbins, 1994. Teori Organisasi : Struktur, Desain, dan Aplikasi, Edisi Ketiga, Alih Bahasa Jusuf Udaya, Arcan, Jakarta.

Sudikno Mertokusumo, 1993. Hukum Acara Perdata Indonesia, Liberty, Yogyakarta.

Susanti Adi Nugroho, 2009. Mediasi Sebagai

Alternatif Penyelesaian Sengketa. Jakarta: PT. Telaga IImu Indonesia.

Suwandi, Made, 2009. Tanggapan Terhadap Makalah Tentang Pokok-Pokok Pikiran Penataan Organisasi Pemerintah Pusat, Pemerintah Daerah Propinsi dan Pemerintah Daerah Kabupaten/Kota, Jakarta.

Syahrizal Abbas, 2011. Mediasi Dalam Perspektif Hukum Syariah, Hukum Adat, Hukum Nasional. Jakarta: Kencana.

Takdir Rahmadi, 2010. Mediasi: Penyelesaian Sengketa Melalui Pendekatan Mufakat. Jakarta: Rajawali Pers.

T Deddy Tikson, dkk. 2004. Evaluasi

Pembangunan

Pasca

Otonomi Daerah di Sulawesi Selatan, Kerjasama Bappeda Propinsi Sulsel dengan Lembaga Penelitian Unhas, Makassar.

Wacipto Setiadi, 1994. Hukum Acara Peradilan Tata Usaha Negara Suatu Perbandingan, PT Raja Grafindo Persada, Jakarta. 


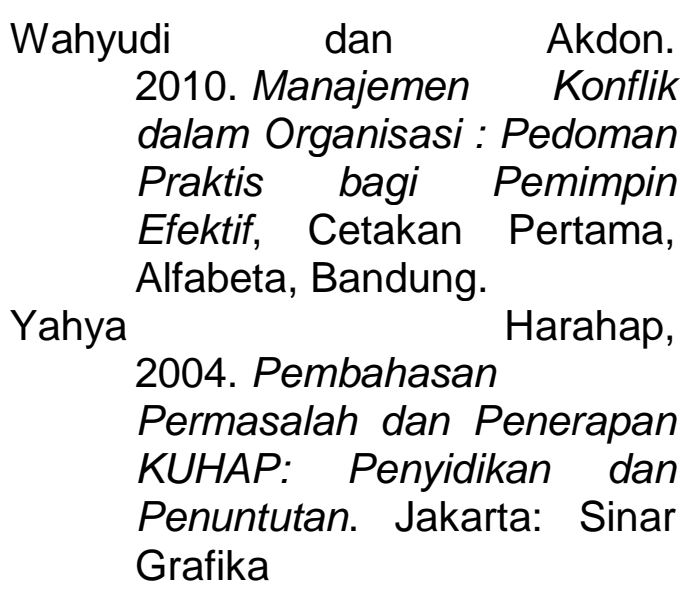

\section{PERUNDANG-UNDANGAN}

Undang-undang Dasar 1945

Undang-Undang No. 14 Tahun 2008 Tentang Keterbukaan Informasi Publik

Peraturan Pemerintah Nomor 61 Tahun 2010 tentang Pelaksanaan Undangundang Nomor 14 Tahun 2008 tentang Keterbukaan Informasi Publik

Peraturan Mahkamah Agung Republik Indonesia Nomor 1 Tahun 2008 tentang Prosedur Mediasi di Pengadilan.

Peraturan Mahkamah Agung No. 02 Tahun 2011 tentang Tata Cara Penyelesaian Sengketa Informasi Publik Di Pengadilan

Peraturan Komisi Informasi Nomor 1 Tahun 2010 tentang Standar Layanan Informasi Publik

Peraturan Komisi Informasi Nomor 1 Tahun 2013 tentang Prosedur Penyelesaian Sengketa Informasi Publik

Peraturan Komisi Informasi Nomor

1 Tahun 2017 tentang Pengklasifikasian Informasi Publik

\section{WEBSITE}

Pengadilan Tata Usaha Menado, Dasar Hukum Keterbukaan Informasi Publik, http://www.ptunmanado.go.i d/index.php?option=com_co ntent $\&$ view $=$ article\&id $=210 \%$ 3Adasar-hukumketerbukaaninformasi

publik\&catid=116\%3Akip\& Ite mid $=1$, diakses tanggal 3

Agustus 2018, pukul 13:00 WIB.

Pejabat Pengelola Informasi dan Dokumentasi Layanan Informasi Publik Sekretariat Jenderal DPR RI, Dasar Hukum Layanan Informasi Publik, http://ppid.dpr.go.id/index/sta tik/id/5, diakses tanggal 3 Agustus 2018, pukul 13:00 WIB 